\title{
Morphological, physiological and behavioral changes during post-hatching development of Octopus maya (Mollusca: Cephalopoda) with special focus on the digestive system
}

\author{
Cintia Moguel ${ }^{1}$, Maite Mascarón ${ }^{2}$, Omar Hernando Avila-Poveda ${ }^{2}$, \\ Claudia Caamal-Monsreal ${ }^{1,2}$, Ariadna Sanchez ${ }^{2}$, Cristina Pascual ${ }^{2}$, Carlos Rosas ${ }^{2, *}$ \\ ${ }^{1}$ Posgrado en Ciencias del Mar y Limnología (PCMyL), Universidad Nacional Autónoma de México (UNAM), \\ Puerto de abrigo S/N, Sisal, Yucatan, Mexico \\ ${ }^{2}$ Unidad Multidisciplinaria de Docencia e Investigación (UMDI), Facultad de Ciencias, UNAM, Puerto de abrigo S/N, Sisal, \\ Yucatan, Mexico
}

\begin{abstract}
We examined changes in the histology, physiology and enzymatic activity of the digestive gland - as well as changes in morphology and feeding behavior - of Octopus maya during rearing, to define the phases characterizing post-hatching development. Morphometric changes showed that juvenile $O$. maya exhibited a non-growth phase during the first $10 \mathrm{~d}$ post-hatching (DPH). Histological analysis revealed that the digestive gland morphology changed with age, from a simple tubular gland in octopuses 2 DPH to a tubulo-acinar and vacuolar structure with digestive cells characterized by vacuoles in octopuses 45 DPH. Digestive enzyme activity was erratic until $14 \mathrm{DPH}$, after which the activity started to stabilize. $O$. maya at 2 and $3 \mathrm{DPH}$ rarely presented attack responses to either visual or both visual and chemical stimuli from prey. In contrast, at $4 \mathrm{DPH}$, octopuses responded to visual stimuli from crabs and palaemonids, but did not display preference in attacking either prey type. Based on our results, we have defined for the first time 2 phases in the early life history of $O$. maya: post-hatching and juvenile.
\end{abstract}

KEY WORDS: Cephalopoda $\cdot$ Digestive gland · Post-hatching development - Digestive enzyme · Feeding behavior - Octopus maya

\section{INTRODUCTION}

Transition from dependence on maternally derived yolk reserves to independent active feeding represents a critical period in the early life history of cephalopods (Portmann \& Bidder 1928, O'Dor \& Wells 1975, Vecchione 1987, Boletzky 1989), similar to the critical period concept described for larval fish (Hjort 1914, Marr 1956, May 1974). Results obtained with Loligo opalescens demonstrated that the high mortalities that occur during the critical period are due to the simultaneous inability of hatchlings to withstand even tempo- rary starvation and capture prey in the required amounts for daily maintenance and growth. These high mortalities were observed during the 'no net growth' phase of $L$. opalescens, i.e. after yolk had been completely exhausted and body weight increased slowly until the original hatchling weight was attained (Vidal et al. 2002). In this species, the nutritional condition of the hatchlings from 5 to $10 \mathrm{~d}$ post-hatching $(\mathrm{DPH})$ at $16^{\circ} \mathrm{C}$, assessed by the RNA:DNA ratio, agrees with survival and growth rates observed by Vidal et al. (2002). The determination of a period of no net growth shows also that hatchling growth was not exponential 
immediately on post-hatching, as previously assumed for squid (Forsythe \& Van Heukelem 1987), and that first-feeding hatchlings were extremely sensitive to starvation. The occurrence of the no net growth phase was only revealed after daily individual weight data had been obtained (Vidal et al. 2002).

In a similar way, Boucaud-Camou \& Boucher-Rodoni (1983) reported that Sepia officinalis hatchlings go through 3 stages that include (1) an embryonic phase characterized by intracellular yolk digestion, linear low growth rate, weak activity of the digestive gland and negative reactions of chymotrypsin, indicating negative extracellular digestion (during these first $4 \mathrm{~d}$ the animals do not eat); (2) a post-hatching phase that begins with the first meal inducing the secretory activity of the digestive gland that has grown at the expense of the inner yolk sac; and (3) a juvenile-adult phase, observed at the end of the first month of life, in which the digestive gland has the same histophysiology as that of adults and in which animals are able to catch a greater variety of prey. In this sense, Budelmann et al. (1997) pointed out that the microscopic anatomy of the digestive gland, like the duct appendages of cephalopods, undergoes a variety of changes during postembryonic and juvenile development that result in diverse anatomical features and functions, although some are not yet completely understood. These include (1) synthesis and secretion of digestive enzymes; (2) absorption and metabolism of nutrients; (3) synthesis and storage of lipids, lipoproteins, glycogen, pigments, vitamins and protein; (4) binding of $\mathrm{Fe}, \mathrm{Cu}, \mathrm{Ca}$ and non-physiological heavy metals; and (5) excretion and rejection of waste products from digestion and cell metabolism.

In the immediate post-hatching period, octopuses show an important lipidic metabolism related to the use of yolk that provides a higher opportunity to survive during the first days, when food may be limited (Segawa \& Hanlon 1988). Experiments on Octopus vulgaris paralarvae (Navarro \& Villanueva 2003) and $O$. maya hatchlings (Rosas et al. 2007) revealed lipidic composition changes with both the age and metabolic capacity of the post-hatching organism indicating that, at this stage, octopuses undergo physiological and morphological adjustments of the internal organs to use nutrients during their development and growth.

In Sepia officinalis (Yim \& Boucaud-Camou 1980), Loligo pealei and L. forbesi (Vecchione \& Hand 1989), the digestive gland develops during the first few DPH. Consequently, an adjustment of enzymatic activity has to occur. This adjustment is a signal of juvenile digestion changing to adult digestion (Yim \& BoucaudCamou 1980, Vecchione \& Hand 1989, Perrin et al. 2004). Perrin et al. (2004) showed increased total trypsin and chymotrypsin activities during juvenile cuttlefish development. Consequently, specific activity of these enzymes decreased between 10 and $30 \mathrm{DPH}$, indicating the transition from intracellular to extracellular digestion. Young \& Harman (1988) defined the cephalopod juvenile stage as the stage between hatchling and subadult, suggesting that all the post-hatching characteristics must be classified as the juvenile stage.

Hatchling growth is highly variable and influenced by biotic and abiotic factors, such as temperature, hatchling size, food type and yolk reserves, among other factors (Vidal et al. 2002, Leporati et al. 2007, Steer \& Moltschaniwskyj 2007, André et al. 2008, Briceño et al. 2009). Like cuttlefish, when Octopus maya hatches, hatchlings are born as holobenthic animals with the same gross anatomical features as adults. However, after 3 yr of $O$. maya hatchling production at Unidad Multidisciplinaria de Docencia e Investigación, Universidad Nacional Autónoma de México (UMDIUNAM), it has been observed that hatchlings pass through a transition period before they acquire all the characteristics that define the juvenile stage (Rosas et al. 2007). In fact, during the first 5 to $10 \mathrm{DPH}$, food consumption is erratic while octopuses swim inside the tank, spending some time on the upper part of artificial grasses (15 cm length), which we offered as additional refuge in rearing conditions (Rosas et al. 2008). Also, we observed that between 5 and $10 \%$ of hatchlings are born with an external yolk sac, suggesting that $O$. maya could be hatched with yolk reserves as observed in $O$. joubini (Boletzky \& Boletzky 1969) and Enteroctopus megalocyathus (Ortiz et al. 2006). Taking into consideration this behavior and previous studies made on $O$. vulgaris paralarvae (Hamazaki et al. 1991, Hamazaki \& Takeuchi 2000), we fed O. maya hatchlings Artemia franciscana adults and crab paste (Callinectes spp.) in an attempt to account for transitional stage by offering both epibenthic and benthic food (Rosas et al. 2008). Thus a reduced response to food during the first few $\mathrm{DPH}$, associated with an external yolk sac, morphological changes in arms and epibenthic behavior, could indicate that $O$. maya goes through complex morphophysiological adjustments during early post-hatching development.

The present study assessed histological, physiological (total lipids and water content) and enzymatic changes in the digestive gland together with morphometric changes (wet and dry body weights and total, dorsal mantle and arm lengths) and post-hatching feeding behavior of Octopus maya to determine how morpho-physiological adjustments occur during early post-hatching development. These data will enable us to explain $O$. maya's adaptation to the benthic environment, as well as provide useful information for its aquaculture. 


\section{MATERIALS AND METHODS}

Collection and maintenance of egg-laying females. Wild Octopus maya females were caught on the continental shelf of the Yucatan Peninsula $\left(21^{\circ} 9^{\prime} 55^{\prime \prime} \mathrm{N}\right.$, $\left.90^{\circ} 1^{\prime} 50^{\prime \prime} \mathrm{W}\right)$ using artisan lines with blue crabs Callinectes spp. as bait; females were transported in $120 \mathrm{l}$ circular tanks with seawater from the port to the UMDI-UNAM laboratory, situated $300 \mathrm{~m}$ inland. In the laboratory, females were maintained in $250 \mathrm{l}$ black tanks until they laid eggs. Eggs and hatchlings were obtained from wild females. For the present study, we used the eggs laid by 10 wild females at various periods between 2007 and 2008 .

Rearing and growth of post-hatchlings. Posthatching juvenile phase individuals were obtained from the Experimental Cephalopod Production Unit (EPHAPU) from the UMDI-UNAM laboratory. Eggs, attached to the cap of the artificial nest, were incubated at $26 \pm 1{ }^{\circ} \mathrm{C}$ in a UV-sterilized seawater flowthrough system. Embryo development takes $50 \mathrm{~d}$ at this temperature (Rosas et al. 2006, Avila-Poveda et al. 2009). At EPHAPU, Octopus maya hatchlings were placed and reared in 10 white 24001 tanks $(2 \times 4 \times$ $0.3 \mathrm{~m}$ ) at densities between 100 and 125 octopuses $\mathrm{m}^{-2}$ for $30 \mathrm{~d}$. During this time, octopuses were fed twice a day (ration of $30 \%$ wet weight [WW]) with Artemia salina adults $8 \mathrm{~mm}$ in length (15 g living biomass tank ${ }^{-1}$ $\mathrm{d}^{-1}$ ) for the first $15 \mathrm{~d}$ and pieces (about $2 \mathrm{~mm}^{2}$ ) of fresh crab meat (Callinectes spp.) for the whole rearing time. Tanks were connected to a recirculating seawater system coupled to a skimmer and sand filters, with a controlled temperature of $26 \pm 2{ }^{\circ} \mathrm{C}$, salinity of $36 \mathrm{ppt}$, dissolved oxygen $>5 \mathrm{mg} \mathrm{l}^{-1}, \mathrm{pH} 8$ or slightly above and a photoperiod of $12 \mathrm{~h}$ light:12 h dark (60 lux $\mathrm{cm}^{-2}$ ). To avoid cannibalism and stress, octopuses were provided with clean conch Melongena corona bispinosa shells to serve as refuges in a proportion of 3 refuges per octopus. A total of 4000 hatchlings from rearing tanks (mean $\pm \mathrm{SD}=0.130 \pm 0.030 \mathrm{~g} \mathrm{WW}$ ) were used in the present study.

Welfare during handling of post-hatchlings. Before the morphometrical and histological evaluations, all octopuses were anesthetized with a $1 \%$ alcohol solution and cool seawater at $5^{\circ} \mathrm{C}$ to assess physiological and digestive enzymes (Roper \& Sweeney 1983), giving consideration to ethics and welfare during the manipulations (Moltschaniwskyj et al. 2007).

Morphometric measurements. During post-hatching development of Octopus maya, total length (TL), dorsal mantle length (DML) and arm length (AL) were measured to the nearest $0.5 \mathrm{~mm}$; total WW and dry weight (DW) $( \pm 0.001 \mathrm{~g})$ were obtained individually (Roper \& Voss 1983). From 1 to $10 \mathrm{DPH}, 3$ groups of 20 octopuses each from 3 different spawns were measured daily. After $11 \mathrm{DPH}$, measurements were only taken at $11,16,20,24,28$ and 30 DPH. A total of 1739 octopuses were randomly sampled to obtain the morphometric changes with age.

Before weighing, each hatchling was rinsed with distilled water to eliminate salt crystals and blotted dry with a paper towel to avoid data overestimation due to water or salt content. Octopuses were dried at $60^{\circ} \mathrm{C}$ and the weight was registered until reaching a constant weight. Body water content (BWC, \%) of the octopuses was calculated as $[(\mathrm{WW}-\mathrm{DW}) / \mathrm{WW}] \times 100$.

Histological procedures and observation methods. A total of 42 O. maya (6.5-19.5 mm TL, 4-9 mm DML, 0.018-0.212 g WW) were used for histological analysis. Thus 14 octopuses were sampled at every 2, 23, and $45 \mathrm{DPH}$. Octopuses were fixed in a $10 \%$ neutral formalin saline solution in seawater for 12 to $15 \mathrm{~d}$ and preserved in $70 \%$ ethanol with $0.1 \%$ glycerin until processing (Roper \& Sweeney 1983). All sampled octopuses were weighed and measured only after preservation (Avila-Poveda et al. 2009).

Octopuses were cut in half lengthwise on sagittal (dorso-ventral orientation) and frontal (lateral orientation) planes and each half was subjected to the following histological routines: washing, dehydration, clearing and embedding (Avila-Poveda et al. 2009). Serial sections of $5 \mu \mathrm{m}$ were cut with a manual rotary microtome (Leica RM 2125) and mounted on glass slides with gelatin. Harris's hematoxylin and eosin, regressive method, was used for staining (Luna 1968).

Digital images and cell measurements of the digestive gland were achieved with a DS-5M-L1 Digital Sight Camera System mounted on a Nikon Eclipse ME-600 microscope. Compound figures were produced on the sagittal plane with around 200 microscopic fields (100x) to show the main features. Adobe Photoshop ${ }^{\circledR}$ CS2, version 9.0, was used for the photographic assembly process.

Physiological data. Digestive gland total lipids were measured daily in 48 octopuses during the first

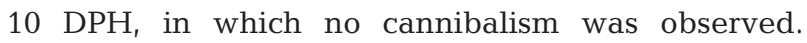
Every day, 16 digestive glands were pooled for total lipid extraction. This procedure was repeated 3 times during the study using hatchlings from 3 different females ( $\mathrm{n}=480$ octopuses; $0.11-0.15 \mathrm{~g} \mathrm{WW}$ ). Extraction of total lipids followed the chloroform-methanol method (Bligh \& Dyer 1959) and involved 3 major steps: (1) pooled digestive glands were homogenized using a 1:1 chloroform:methanol solution; (2) homogenates were filtered and placed in a funnel to separate the chloroform layer; and (3) after phase equilibration, the lower chloroform layer (total lipids) was removed, concentrated and weighed. Total lipids were expressed as milligrams of lipids per gram of fresh tissue analyzed. 
Digestive enzyme measurements. Enzymatic activity was measured daily in 20 octopuses during the first $30 \mathrm{DPH}$. In this part of the study, 600 hatchlings spawned from a single female were distributed in 6 black $750 \mathrm{l}$ tanks $(1 \times 1.5 \times 0.5 \mathrm{~m})$ at densities of 66 octopuses $\mathrm{m}^{-2}$ following the maintenance, feeding and rearing parameters previously mentioned. A $5 \pm 1 \%$ cannibalism rate was recorded in these tanks.

All octopuses were deprived of food for $12 \mathrm{~h}$ before sampling. Digestive glands were dissected and stored at $-80^{\circ} \mathrm{C}$ until analysis. For acidic phosphatase determination, frozen samples were homogenized in a $1 \%$ $\mathrm{KCl}$ and $1 \mathrm{mM}$ EDTA solution at $4^{\circ} \mathrm{C}$. For total protease, trypsin and chymotrypsin determinations, samples were homogenized using a Tris-base buffer (0.09 M Tris-base, $0.08 \mathrm{M}$ boric acid, $3 \mathrm{mM}$ EDTA, $0.5 \mathrm{M}$ mercaptoethanol, $10 \%$ glycerol, $\mathrm{pH} 8.3$ ) at $4^{\circ} \mathrm{C}$. Homogenates were centrifuged at $10000 \times g$ for $30 \mathrm{~min}$ at $4^{\circ} \mathrm{C}$ and the supernatant was diluted in 10 volumes of ice-cold pyrogen-free water. Homogenates were immediately used for enzyme analyses. The solubleprotein content was measured in diluted homogenates (Bradford 1976) using the Bio-Rad protein determination kit (500-0006).

General protease activity was measured in homogenates using azocoll (Sigma, A-4341) as substrate in phosphate buffer at $\mathrm{pH}$ 8. Absorbance was read in a spectrophotometer (Spectronic, model 21D) at $520 \mathrm{~nm}$. One unit was defined as the amount of enzyme that catalyzes the release of azo dye causing a $\Delta A / \Delta t=$ $0.001 \mathrm{~min}^{-1}$, where $\Delta A$ shows the differences between optical densities obtained during the time of the experiment $(\Delta t)$ (Walter 1984). Assays were duplicated for each sample. Trypsin activity was measured in diluted homogenates (1:100) using $1100 \mathrm{mM}$ benzoil-argininepara-nitro-anilide (BAPNA) as substrate in a buffer at pH 8 (0.1 M Tris, $0.05 \mathrm{M} \mathrm{NaCl).} \mathrm{Samples} \mathrm{were} \mathrm{incu-}$ bated at $25^{\circ} \mathrm{C}$ for $1 \mathrm{~h}$. Absorbance was read at $410 \mathrm{~nm}$. Chymotrypsin activity was measured in diluted homogenates (1:100) using $1142 \mathrm{mM}$ succinil-Ala-Ala-ProPhe-p-nitro-anilide (SAPNA) as a substrate in a buffer at pH $8\left(0.1 \mathrm{M}\right.$ Tris-base with $\left.0.01 \mathrm{M} \mathrm{CaCl}_{2}\right)$. Samples were incubated at $37^{\circ} \mathrm{C}$ for $30 \mathrm{~min}$ and read at $410 \mathrm{~nm}$. Acidic phosphatase was measured using p-nitrophenil-phosphate $(2 \%)$ in a buffer at $\mathrm{pH} 4(1 \mathrm{M}$ Tris-HCl). The sample was incubated at $25^{\circ} \mathrm{C}$ for $30 \mathrm{~min}$, and the reaction was stopped by adding $1 \mathrm{ml}$ of $1 \mathrm{M} \mathrm{NaOH}$. Absorbance was read at $405 \mathrm{~nm}$. All enzyme activities are expressed as international units (IU) per milligram of protein.

Predatory behavior. To examine the attack response of Octopus maya to visual and chemical stimuli, 3 experiments were conducted in which octopuses were not allowed any physical contact with the prey (Table 1). Expts 1 and 3 exposed octopuses only to visual stimuli from the prey, while Expt 2 exposed octopuses to both visual and chemical stimuli. In order to examine the predatory response of octopuses, a fourth experiment was performed in which individuals had free access to both prey types (Table 1 ). The frequencies observed in Expts 1, 2 and 3 corresponded to the number of responses/no-responses to crabs $(n=2)$ and/or palaemonids $(\mathrm{n}=3)$ per octopus, and added up to a total of 42 events (14 octopuses $\times 3$ treatments) in each experiment. Observed frequencies in the predation experiment corresponded to the number of prey consumed/not consumed by each of 12 octopus (4 octopuses $\times 3$ treatments), adding up to a total of 48 prey items offered ( 4 prey items $\times 4$ octopuses $\times 3$ treatment; Table 1). Hatchlings had no visible external yolk and had never been exposed to any type of food prior to these experiments. Care was taken so that individuals were used only once throughout all experiments. The TL of palaemonids and carapace width $(\mathrm{CW})$ of crabs used as prey items was either less than or equal to the octopus DML.

Attack response experiments were carried out by placing octopuses individually in transparent plastic chambers $(4 \times 4 \times 9 \mathrm{~cm})$ provided with a black sliding door. Prey were placed in similar chambers $(2 \times 3 \times$ $9 \mathrm{~cm}$ ) with all sides fixed. Prey chambers were air-tight in Expts 1 and 3, but had small perforations in Expt 2

Table 1. Octopus maya. Data on hatchling feeding-behavior experiments, including age (days post-hatching, DPH) and wet weight (WW, g) of hatchlings, number of hatchings per treatment $\left(\mathrm{N}_{\mathrm{h}}\right)$ treatment type and total number of items in contingency tables for each treatment $\left(\mathrm{N}_{\text {tot }}\right)$. NCH1: no choice treatment with crabs (cra) only; NCH2: no choice treatment with palaemonids (pal) only; $\mathrm{CH}$ : choice treatment with crabs and palaemonids

\begin{tabular}{|lccccc|}
\hline Experiment & Age (DPH) & WW $(\mathrm{g})$ & $\mathrm{N}_{\mathrm{h}}$ & Treatment & $\mathrm{N}_{\text {tot }}$ \\
\hline (1) Visual stimulus & 2 & $0.100 \pm 0.02$ & 14 & NCH1: 2 cra & $42(14 \times 3)$ \\
(2) Visual + chemical stimuli & 3 & $0.110 \pm 0.02$ & 14 & NCH2: 3 pal & $42(14 \times 3)$ \\
(3) Visual stimulus & 4 & $0.110 \pm 0.02$ & 14 & CH: 2 cra +3 pal & $42(14 \times 3)$ \\
(4) Predation & 4 & $0.130 \pm 0.02$ & 4 & NCH1: 4 cra & $48(4 \times 4 \times 3)$ \\
& & $0.129 \pm 0.02$ & & NCH2: 4 pal & CH: 2 cra +2 pal \\
\hline
\end{tabular}


to allow contact with chemical stimuli from palaemonids. Both octopus and prey chambers were, in turn, placed within glass aquaria $(10 \times 15 \times 12 \mathrm{~cm})$ with airsaturated water at a salinity of 36 at $27^{\circ} \mathrm{C}$. Aquaria were visually isolated from each other with black plastic divisions to reduce stress levels in the octopuses.

After $8 \mathrm{~min}$ of acclimation time, the sliding door of the octopus chamber was removed, and all movements were recorded with a video camera (Sony Handycam HDV 108i, HDR-HCR, 4.0 megapixels) for $15 \mathrm{~min}$. An attack response was defined as directed swimming or crawling towards either prey chamber, and repeated attempts to introduce tentacles into the chamber (Mascaró \& Seed 2001). When the octopus remained motionless or presented an erratic movement, the lack of response was registered and considered as such in the analysis.

The predation treatment was carried out in chambers and aquaria similar to those used previously, but individual octopuses and prey were placed together within the aquaria to allow free access to live food. After $4 \mathrm{~h}$, the number of prey items consumed by octopuses was registered. In order to discount that octopus were unable to pursue and capture the prey offered, but otherwise willing to feed on an external source, 4 additional individuals were offered $0.08 \mathrm{~g}$ of a semimoist crab paste in an empty clam shell, and the number of octopuses feeding on the paste was registered once every hour. The paste was made mixing crab meat with $5 \%$ natural gelatin (Rosas et al. 2008).

\section{RESULTS}

\section{Morphometric changes}

A mean WW value of $0.126 \pm 0.030 \mathrm{~g}$ was obtained for Octopus maya post-hatching. No significant changes in WW were observed during the first $10 \mathrm{DPH}$ ( $p>0.05$ ); for that reason a mean WW of $0.12 \pm 0.03 \mathrm{~g}$ was calculated for $O$. maya hatchlings for that period (Table 2). An exponential growth curve was calculated describing the WW changes for first 30 DPH (Fig. 1); WW variation increased with age during that period.

Erratic values were observed in TL measurements of Octopus maya hatchlings. During the first $10 \mathrm{DPH}, \mathrm{TL}$ values oscillated between 2.2 and $2.8 \mathrm{~cm}$ (Fig. 2A). Higher TL values were observed in octopuses at 1, 5, 8, and $10 \mathrm{DPH}$ (mean $=2.7 \mathrm{~cm}$ ) than those observed in the rest of these first $10 \mathrm{DPH}$ sampled $($ mean $=2.29 \mathrm{~cm}$, p $<0.05$; Fig. 2A).

A reduction in DML was observed according to time after hatching with higher values at $1 \mathrm{DPH}$ (mean = $1.08 \mathrm{~cm}$ ) than the rest of these first $10 \mathrm{DPH}$ sampled (mean $=0.78 \mathrm{~cm}, \mathrm{p}<0.05$; Fig. 2B). In contrast, $\mathrm{AL}$
Table 2. Octopus maya. Variation in wet weight (WW, g) of $O$. maya at different times during the first $30 \mathrm{~d}$ post-hatching $(\mathrm{DPH})$. Data are mean $\pm \mathrm{SD} . \mathrm{N}_{\text {tot }}$ : total number of octopuses

\begin{tabular}{|lcr|}
\hline DPH & WW $(g)$ & $N_{\text {tot }}$ \\
\hline 1 & $0.126 \pm 0.03$ & 553 \\
2 & $0.092 \pm 0.02$ & 50 \\
3 & $0.099 \pm 0.02$ & 50 \\
4 & $0.129 \pm 0.02$ & 50 \\
5 & $0.114 \pm 0.02$ & 50 \\
6 & $0.084 \pm 0.02$ & 50 \\
7 & $0.106 \pm 0.01$ & 50 \\
8 & $0.128 \pm 0.02$ & 50 \\
9 & $0.116 \pm 0.03$ & 50 \\
10 & $0.124 \pm 0.03$ & 50 \\
11 & $0.101 \pm 0.02$ & 50 \\
16 & $0.281 \pm 0.05$ & 50 \\
24 & $0.457 \pm 0.11$ & 50 \\
30 & $0.637 \pm 0.28$ & 252 \\
Total & & 1405 \\
\hline
\end{tabular}

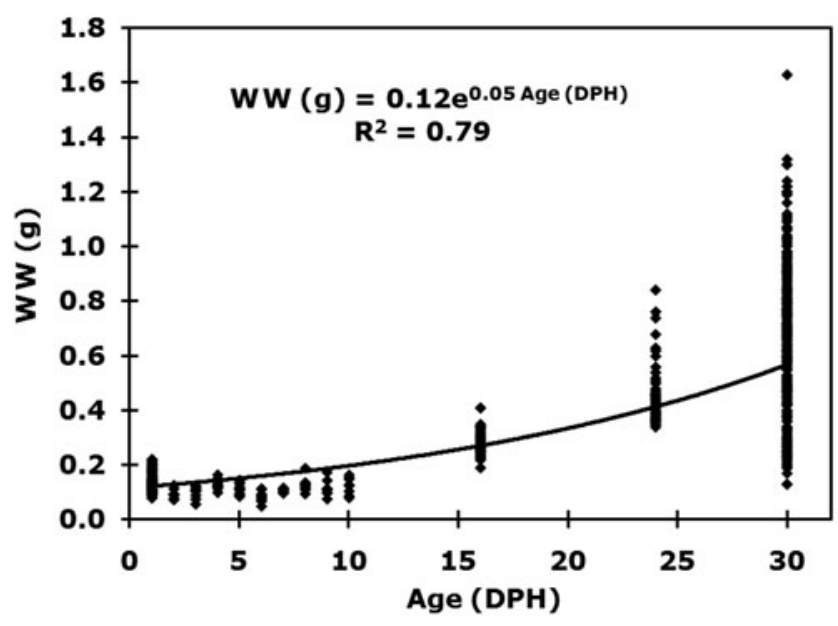

Fig. 1. Octopus maya. Changes in wet body weight (WW, g) during the first $30 \mathrm{~d}$ post-hatching (DPH) of O. maya

increased according to octopus age, with low values from 1 to $7 \mathrm{DPH}($ mean $=1.31 \mathrm{~cm})$, intermediate values at 8 and $9 \mathrm{DPH}$ (mean $=1.64 \mathrm{~cm}$ ) and high values at $10 \mathrm{DPH}$ (mean $=1.8 \mathrm{~cm}, \mathrm{p}<0.05$; Fig. 2C).

A reduction in the DML:TL ratio was observed, with higher values during the first $2 \mathrm{DPH}$ (mean $=0.39$ ) than the rest of these first $10 \mathrm{DPH}$ sampled (mean $=0.31, \mathrm{p}<$ 0.05; Fig. 3A). In contrast, the AL:TL ratio increased with age, with low values from 1 to $8 \mathrm{DPH}$ (mean = 0.55 ) and high values at 9 and $10 \mathrm{DPH}$ (mean $=0.66$, $\mathrm{p}<0.05$; Fig. 3B). The AL:DML ratio increased after hatching with lower values in octopuses from 1 to $8 \mathrm{DPH}($ mean $=1.71)$ than from 9 to $10 \mathrm{DPH}($ mean $=$ 2.23, p < 0.05; Fig. 3C). 

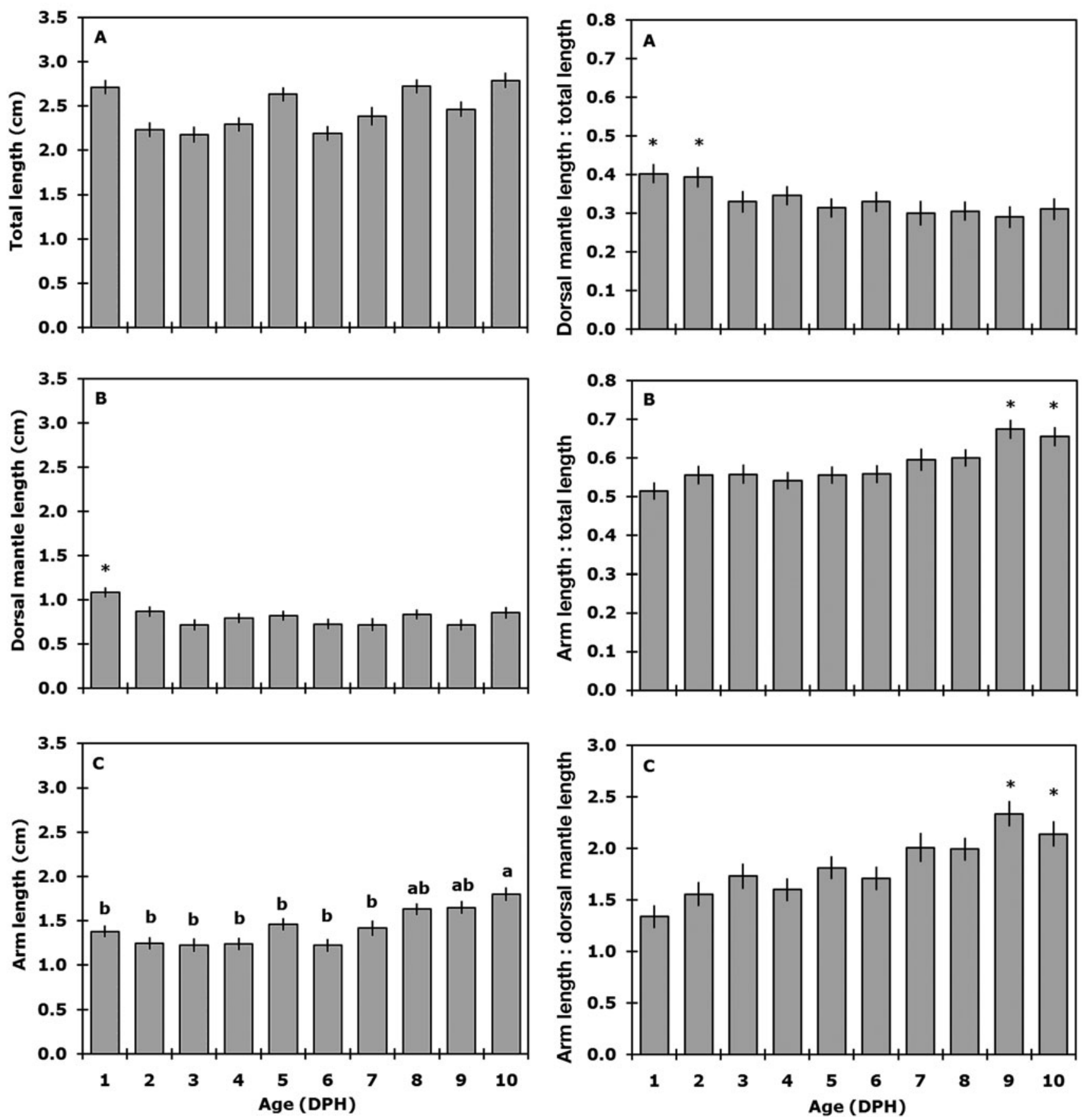

Fig. 2. Octopus maya. Morphometric changes in (A) total length, (B) dorsal mantle length and (C) arm length of $O$. maya during the first $10 \mathrm{~d}$ post-hatching (DPH). Data are mean \pm SE. Asterisks denote significant differences from all other DPH samples at $\mathrm{p}<0.05$. Different letters indicate significant differences amongst values at $p<0.05$

\section{Histological changes in the digestive gland}

The digestive gland of Octopus maya is a conspicuous wedge-shaped organ that dominated three-fourths of the mantle cavity (Fig. 4) and, together with the pos-

Fig. 3. Octopus maya. Morphometric ratio changes of $O$. maya during the first $10 \mathrm{~d}$ post-hatching (DPH). (A) Dorsal mantle length:total length, (B) arm length:total length and (C) arm length:dorsal mantle length. Data are mean \pm SE. Asterisks denote significant differences from all other DPH samples at $p<0.05$

terior salivary gland, was enclosed in a sheath of longitudinal muscle (see also Avila-Poveda et al. 2009, to $60 \mathrm{DPH})$. Internally, the digestive gland showed a changing structure with growth. Octopuses at $2 \mathrm{DPH}$ (Fig. 4A) exhibited a simple tubular gland, containing 

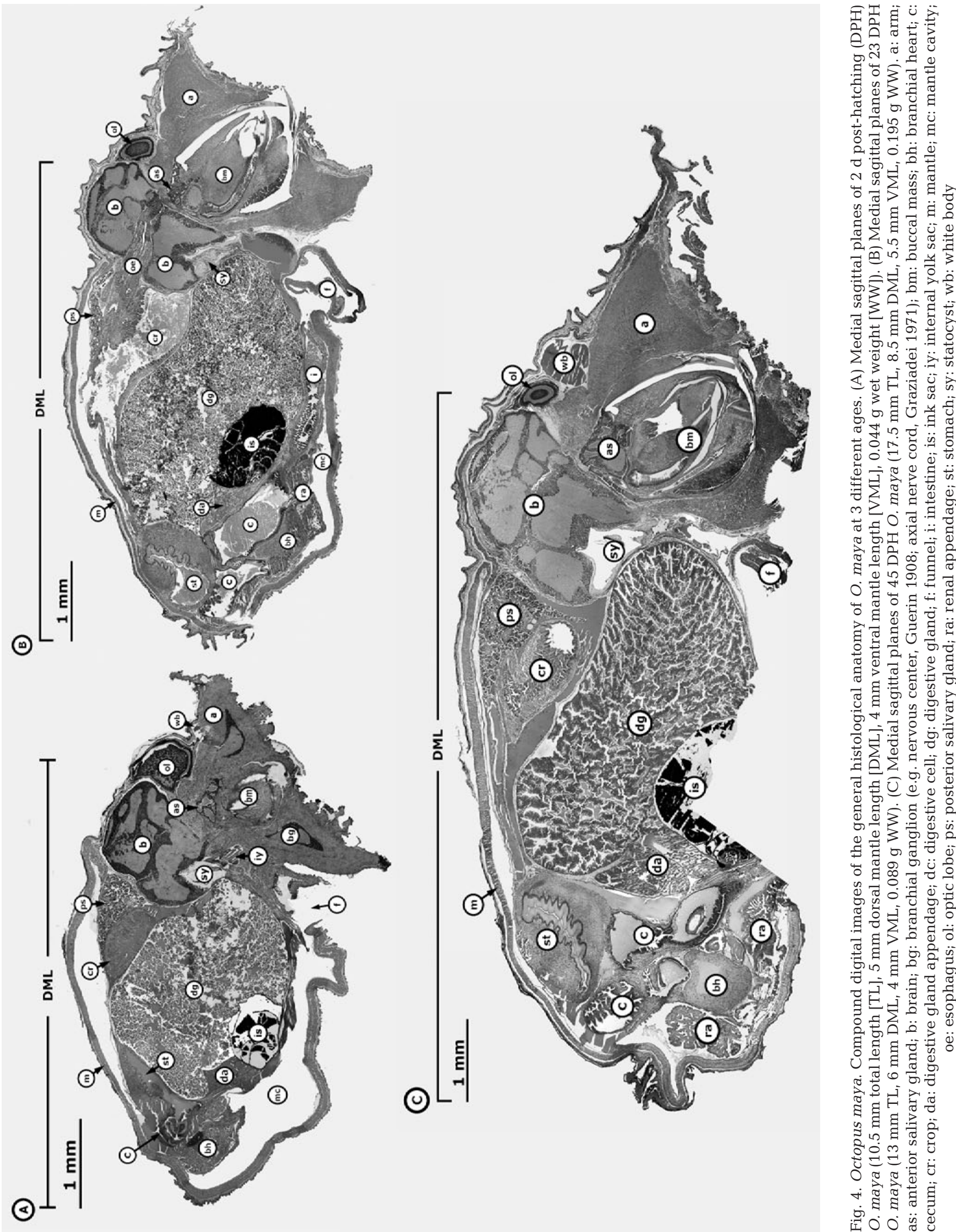


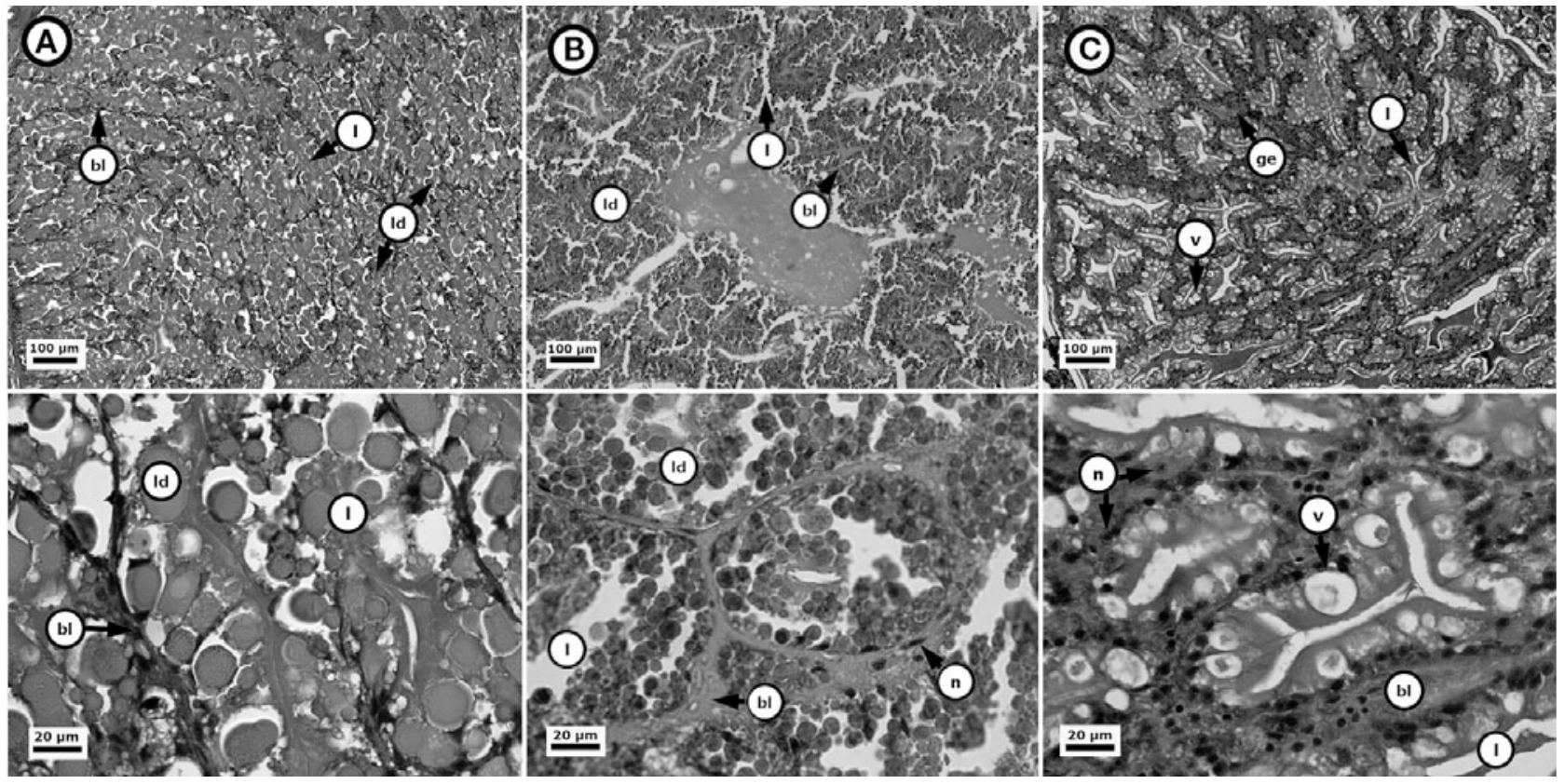

Fig. 5. Octopus maya. Frontal sections of the digestive gland stained with Harris's hematoxylin and eosin. Individuals at (A) $2 \mathrm{DPH}$, (B) $23 \mathrm{DPH}$ and (C) $45 \mathrm{DPH}$ (showing the glandular epithelium). Lower panels represent magnification of upper panels. bl: basal lamina of the tubule; ge: glandular epithelium; l: lumen; ld: lipid droplet in the tubules; n: nucleus; v: vacuole

only a dense accumulation of yolk droplets with an average diameter of $15 \mu \mathrm{m}$, where only the basal lamina and the start of the lumen were evident (Fig. 5A).

At around 23 DPH (Fig. 4B), the digestive gland of Octopus maya was still a simple tubular gland structure (as at 2 DPH) containing lipid droplets, but these were smaller with an average diameter of $7 \mu \mathrm{m}$. The lumen was predominantly bigger and the basal lamina was more conspicuous and wider than in 2 DPH octopuses (Fig. 5B).

At $45 \mathrm{DPH}$ (Fig. 4C), the digestive gland acquired a tubulo-acinar and vacuolar structure that consisted of an acinar glandular portion with a berry-shaped termination (acinar) where the secretion is produced and a duct portion that secretes its product (Fig. 5C). The glandular epithelium of the digestive gland sat on a conspicuous basal lamina. The epithelium appeared homogeneous and contained vacuoles (boules), where each cell possessed a round basal nucleus with a diameter of $3 \mu \mathrm{m}$. The digestive cells were characterized by having vacuoles with an average diameter of $10 \mu \mathrm{m}$ (Fig. 5C).

\section{Physiological changes}

We observed a reduction in total lipids according to age, with higher values at 1 and $2 \mathrm{DPH}$ (mean = $23.58 \mathrm{mg} \mathrm{g}^{-1}$ ) and the lowest values at 8 and $10 \mathrm{DPH}$ $\left(\right.$ mean $=10.98 \mathrm{mg} \mathrm{g}^{-1}, \mathrm{p}<0.05$; Fig. 6A). In contrast, BWC increased with age, with lower values at the posthatching period ( 1 and $2 \mathrm{DPH}$, mean $=75.25 \%$ ) than the rest of these first $10 \mathrm{DPH}$ sampled (mean $=80.17 \%$, $\mathrm{p}<0.05$; Fig. 6B).

\section{Digestive enzyme changes}

During the first $15 \mathrm{DPH}_{\text {, octopuses showed erratic }}$ enzymatic activities (Fig. 7). Peaks in the activity of all enzymes (i.e. protease, phosphatase, chymotrypsin and trypsin) were observed at 3, 5, 9 and $14 \mathrm{DPH}$. Enzymatic activity stabilized between 15 and $26 \mathrm{DPH}$, after which it increased (Fig. 7).

\section{Predatory behavior}

Octopus maya at 2 and 3 DPH very rarely presented attack responses to either visual or both visual and chemical stimuli from prey. Most octopuses stayed motionless within their chambers or slowly slithered to a corner of the aquarium and remained inactive for the rest of the recording session.

In contrast, $54.8 \%$ (23 of 42 ) of octopuses at $4 \mathrm{DPH}$ responded with attacks to visual stimuli from crabs and palaemonids, but only displayed a preference when prey were presented simultaneously (attacks on crabs 

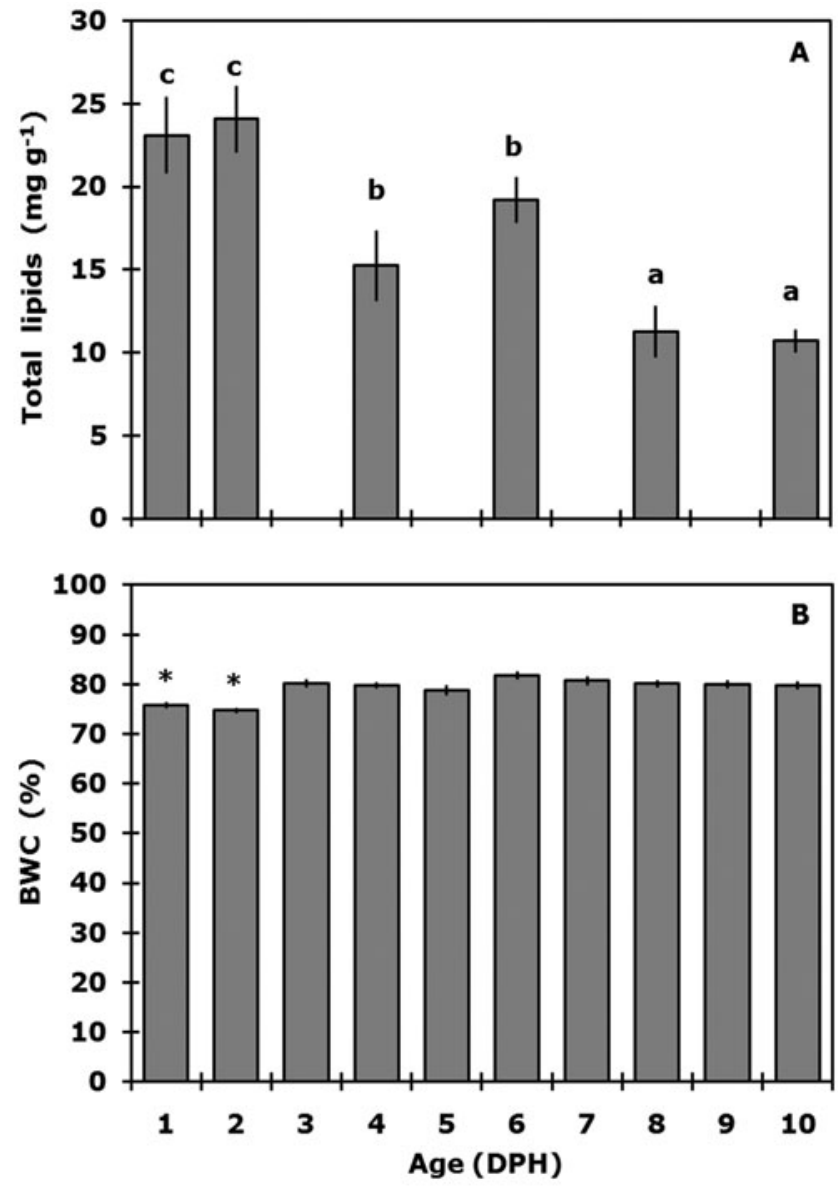

Fig 6. Octopus maya. (A) Total lipids ( $\mathrm{mg} \mathrm{g}^{-1}$ ) and (B) body water content (BWC, \%) of $O$. maya during the first $10 \mathrm{~d}$ posthatching $(\mathrm{DPH})$. Values are given as means \pm SE. Asterisks denote significant differences from all other DPH samples at $p<0.05$. Different letters indicate significant differences amongst values at $\mathrm{p}<0.05$
$66 \%$, palaemonids $20 \%$; treatment $\mathrm{CH}$, Fig. 8), although the difference in attack frequency was statistically similar in treatments where each prey was presented separately $\left(\chi^{2}=0.42, \mathrm{p}=0.52\right)$.

Results from the predation experiments (Expt 4, Table 1 ) showed that only $31 \%$ (5 of 16) of the octopuses consumed live food (Treatment NCH2) and feeding from the semi-moist paste was never observed (Treatment NCH1). The octopuses in the NCH2 treatment consumed 5 palaemonids, whereas those in the $\mathrm{CH}$ treatment only consumed 2 . No crabs were consumed in the $\mathrm{CH}$ treatment, thereby hampering the statistical analysis of the contingency table (Fig. 9).

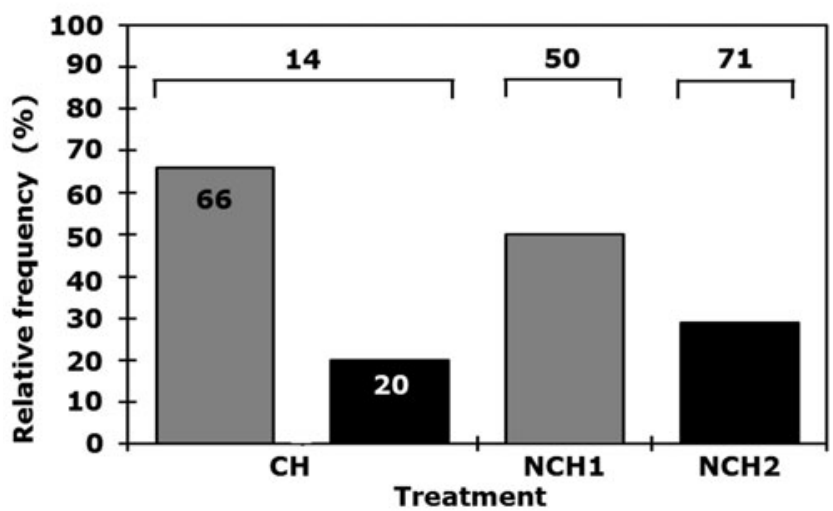

Fig. 8. Octopus maya. Relative frequency (\%) of attack responses in $O$. maya $(\mathrm{n}=42) 4 \mathrm{~d}$ post-hatching $(\mathrm{DPH})$ to visual stimuli from crabs (gray) and palaemonids (black). Each octopus was either presented with visual stimuli from 2 crabs and 3 palaemonids simultaneously (Treatment $\mathrm{CH}$ ), 2 crabs (Treatment NCH1) or 3 palaemonids (Treatment NCH2). The percentage of octopuses that did not respond to stimuli in each treatment is given (horizontal lines)
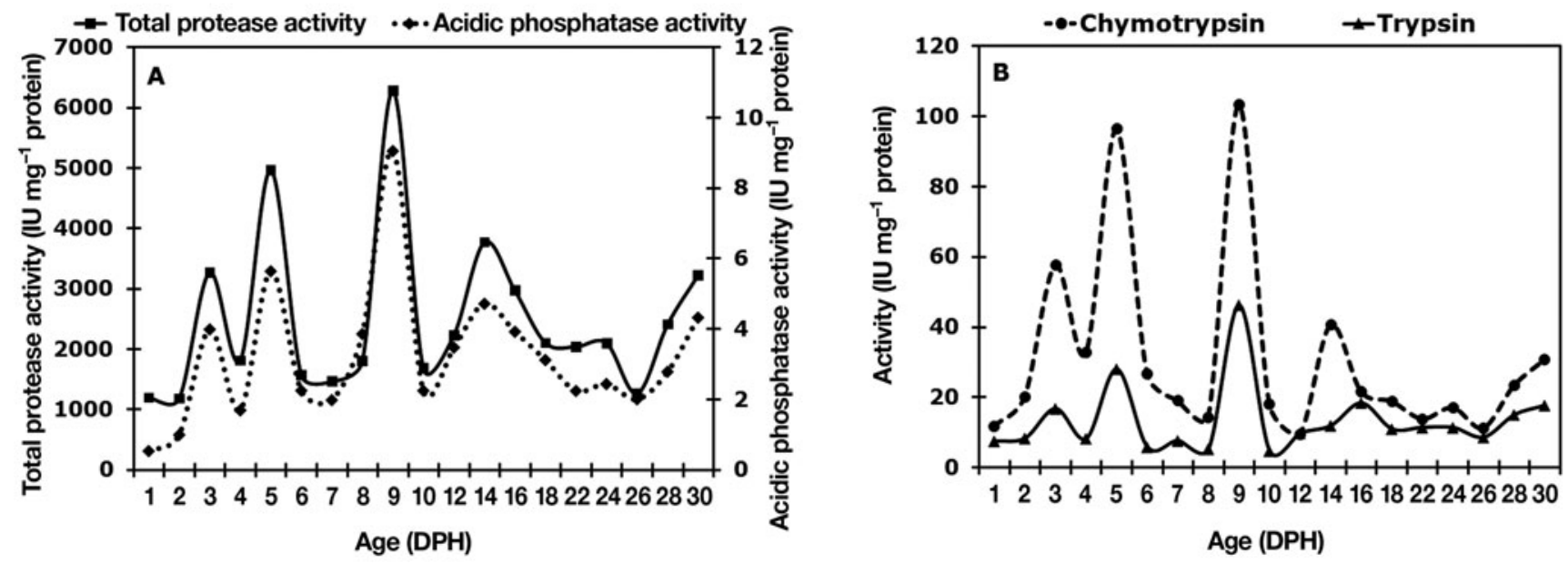

Fig. 7. Octopus maya. Digestive enzyme activity changes in O. maya hatchlings during the first $30 \mathrm{~d}$ post-hatching (DPH). (A) Total acidic protease and acidic phosphatase. (B) Chymotrypsin and trypsin. Data are mean \pm SE. IU: inter-national units 


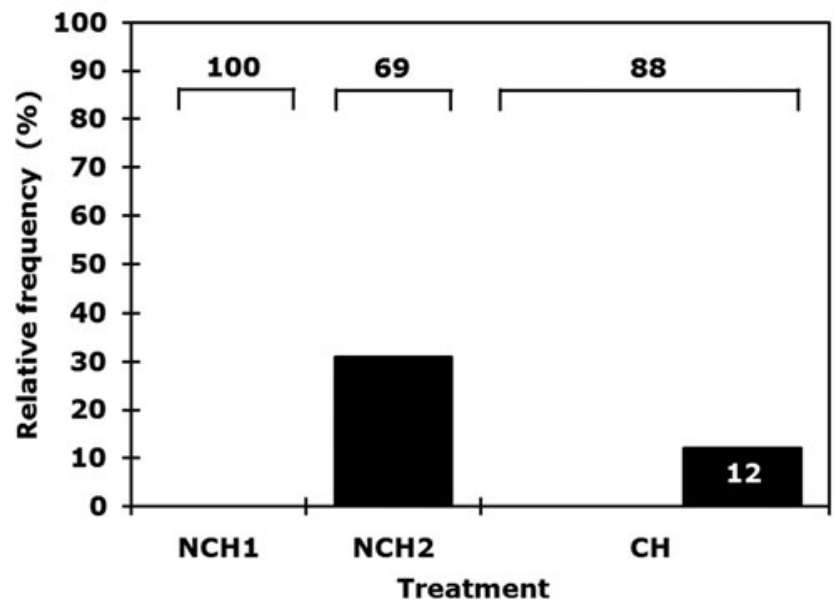

Fig. 9. Octopus maya. Relative frequency (\%) of crabs (white bars $=0$ ) and palaemonids (black bars) consumed by $O$. maya 4 d post-hatching (DPH) ( $\mathrm{n}=12$ octopuses). Each octopus was either presented with 4 crabs (Treatment NCH1), 4 palaemonids (Treatment NCH2) or 2 crabs and 2 palaemonids simultaneously (Treatment $\mathrm{CH}$ ). The percentage of prey items that were not consumed in each treatment is given (horizontal lines)

\section{DISCUSSION}

Our results demonstrate that during the post-hatching period, Octopus maya preserve embryonic characteristics such as relatively short arms, inner yolk sac, digestive immaturity and limited predatory behavior. During the first weeks of the post-hatching period, many cephalopods go through a critical transition before reaching the full juvenile stage (Young \& Harman 1988). In O. maya, this transition is characterized by major changes in morphology, physiology and behavior. Based on the present results, we have defined 2 phases, a post-hatching phase and a juvenile phase, for the early life history of $O$. maya.

During the post-hatching phase, Octopus maya hatchlings present some particular characteristics: (1) necto-benthic behavior; (2) no response to stimuli from prey or an unselective response towards different crustacean prey; (3) a no net growth phase; (4) arms proportionally shorter than the mantle, suggesting a limited predatory capacity; (5) reduction in total body lipid concentration, indicating yolk lipids could be used as the main source of energy; (6) presence of residual inner yolk sac and immature digestive gland cells; and (7) erratic digestive enzymatic activity, indicating an undeveloped digestive gland that could limit digestive capacity.

In contrast, the juvenile phase showed (1) a benthic behavior; (2) a selective response towards different crustacean prey (Rosas et al. 2008); (3) an exponential growth phase; (4) arms proportionally higher than the mantle (allometric growth, Avila-Poveda et al. 2009);
(5) an external source of nutrients and energy from food; (6) digestive gland cells completely developed with vacuoles and boules; and (7) stable enzymatic activity in digestive gland.

\section{Morphometric and physiological changes}

As in other cephalopods (Boucher-Rodoni et al. 1987, Vidal et al. 2002), immediately after hatching and during the first 2 to $3 \mathrm{DPH}$, Octopus maya presumably uses yolk reserves as the main energy source. In fact, a reduction in mantle length was observed, showing how internal spaces within the mantle cavity were reduced after yolk absorption. At this stage, octopuses did not react to either visual stimuli alone (Expt 1) or to both visual and chemical stimulus (Expt 2) from prey, revealing that the lack of response was not due to the type of stimuli presented. Octopuses at $5 \mathrm{DPH}$, however, showed ample attack responses to visual stimuli from both palaemonids and crabs (Expt 3). Because prey types used in these treatments were frequently consumed by adult conspecifics (authors' pers. obs.) and O. maya hatchlings were never in contact with prey of any type prior to the treatments, the lack of a predatory response in Expts 1 and 2 cannot be explained in terms of the type of prey used. Hatchling production at UMDIUNAM suggests that post-hatching octopuses ignore potential prey as long as the inner yolk has not been completely absorbed, but will respond to visual stimuli based on movement, body shape, prey size and probably contrast using a different visual signal selectively (Langridge 2009), but not color, since there is evidence that octopuses and cuttlefish are color-blind (see Messenger 1977, Flores 1983, Mäthger et al. 2006). Sepia officinalis, another cephalopod with direct development, does not attack prey within the first 24 to $48 \mathrm{~h}$ post-hatching, a behavior that has also been correlated with a period of yolk absorption (Wells 1958). Active feeding in cuttlefish, however, can begin before yolk reserves are entirely consumed (Boletzky 1975, Fioroni 1990), and O. maya older than 5 DPH have been observed to feed on adult Artemia salina and frozen crab meat in the laboratory.

We also observed that Octopus maya hatchlings did not exhibit positive growth during the first $10 \mathrm{DPH}$, reflecting the strong physiological and morphological adjustments that are present during the post-hatching phase of octopus development. According to Boletzky (1975) and Boletzky \& Boletzky (1973), the yolk reserves are separated from the digestive gland of cephalopods by a sheath of connective tissue surrounding this organ, as we observed in the present study with $O$. maya. In fact, the same authors defined 
the 'yolk organ' as an independent unit directly connected to the venous system, permitting these cephalopods to both use yolk reserves and to obtain exogenous prey during the first DPH. Vidal et al. (2002) observed that feeding took place while yolk reserves were being digested by the squid Loligo opalescens, and concluded that external food was used to compensate the energy debt associated with the energy invested into the respiratory metabolism during the first DPH. Vidal et al. (2002) also observed that absorption of yolk reserves and first external food consumption coincided with a no net growth phase (between 7 to $15 \mathrm{DPH}$, depending on temperature) during which the equilibrium between yolk reserves and the quality and quantity of the first food could be critical for survival to the next juvenile phase of octopus life.

In the present study, high growth variability was observed between animals maintained in culture tanks. The increase in size variation as individuals age has been called growth depensation (Pfister \& Stevens 2002) and has been extensively documented in fishes (Smith \& Fuiman 2003) and other taxa (see Pfister \& Stevens 2002). In a recent study, Briceño et al. (2009) observed that growth depensation was not explained by intrinsic variability in initial octopus weight, but by some other biological variables which amplify the differences in octopus weight as the animals grow. Other effects, such as those of multiple paternity (Shaw \& Sauer 2004, Voight \& Feldheim 2009), inter-individual variation in feeding and conversion rates (Semmens et al. 2004, André et al. 2008) and the precocity of cephalopod sexual maturation (Avila-Poveda et al. 2009) should be studied in order to understand the adaptations of Ocotpus maya and other cephalopods that allow them to benefit from variable growth.

\section{Histological changes of the digestive gland}

Boucaud-Camou \& Boucher-Rodoni (1983) and Boucher-Rodoni et al. (1987) observed proteinaceous inclusions (boules), together with a secretion with high proteolytic activity filling the lumen of the tubules in the digestive gland of Sepia officinalis juveniles. In the prsent study it was also evident from histological observations that digestive gland cells of Octopus maya hatchlings have no vacuoles or boules, indicating, as in Loligo pealei, L. forbesi (Vecchione \& Hand 1989) and Sepia officinalis hatchlings (Yim \& BoucaudCamou 1980), that the digestive capacity of these octopuses could be limited. Nevertheless, O. maya at $45 \mathrm{DPH}$ (jveniles) in the present study showed welldefined digestive gland cells with vacuoles, boules and a more conspicuous and wider basal lamina, suggesting a maturation process. Although at this time we have not determined if O. maya exhibit digestive cell differentiation, the digestive gland maturation process is similar to that described during postembryonic development in L. pealei and L. forbesi (Vecchione \& Hand 1989) and S. officinalis (Yim \& Boucaud-Camou 1980). It is interesting to note that the simple tubular structure of the digestive gland underwent 2 characteristic changes and, until at least $23 \mathrm{DPH}$, its digestive cells showed activity with respect to (1) consumption of droplets, i.e. from plentiful and larger droplets $(15 \mu \mathrm{m}$ diameter) to scarce and smaller droplets $(7 \mu \mathrm{m}$ diameter); and (2) emptying of the glandular lumen (i.e. predominantly full to empty). Changes in the structure of the gland, with an increase or decrease in the number of spheres and droplets and a filled or unfilled glandular lumen, suggest a feeding process that stimulates the digestive gland to secrete large amounts of enzymes. Semmens (1998, 2002), Swift et al. (2005) and Moltschaniwskyj \& Johnston (2006) indicated that the digestive processes in the digestive gland are the natural pattern before, during and after feeding in cuttlefish and squid.

\section{Digestive enzyme changes}

During the post-hatching phase, digestive enzymes of Octopus maya showed erratic behavior, indicating lapses of synthesis in the digestive gland cells coupled with the maturation process of the digestive gland. During this process, extracellular digestion was evidenced by trypsin and chymotrypsin activities that, together with other enzymes, are in charge of the first digestions. Although activity of acid phosphatase was also observed in digestive gland extracts, the magnitude of this activity was lower than that of the extracellular digestive enzymes, suggesting that extracellular digestion could play a key role in digestive gland maturation. Boucher-Rodoni et al. (1987) hypothesized that exogenous feeding could trigger digestive gland cell differentiation of Sepia officinalis. If this works also for $O$. maya, we can propose that, as a product of extracellular digestion, molecules from the chyme are responsible for stimulating the digestive gland cells, favoring cell differentiation. This would explain why extracellular digestion could be important as a first step of the digestive process in O. maya. This mechanism could be different from that proposed for $S$. officinalis, where intracellular digestion has been identified as the first step during the maturation of the digestive process (Boucher-Rodoni et al. 1987). The appearance of welldeveloped digestive gland cells and plenty of boules in $23 \mathrm{DPH}$ and older octopuses demonstrated that $O$. maya reached its digestive maturity during the time when enzyme activity is stable. At that age, we pro- 
pose that octopuses can definitely be defined as juveniles. However, at this moment it is unclear if, through the rearing conditions we imposed on O. maya hatchlings, we forced octopuses to reduce physiological and morphological adjustments of the digestive gland to use nutrients during their development and growth. It is likely that octopuses, fed twice a day with crab, would express their maximum growth rate $\left(6 \% \mathrm{~d}^{-1}\right)$ and, consequently, exhibit normal physiological and morphological characteristics.

\section{Predatory behavior}

The necto-benthic behavior observed in Octopus maya hatchlings has also been observed in other cephalopod species. Based on the number of suckers of young benthic $O$. joubini (25 to 26 suckers), Boletzky \& Boletzky (1969) concluded that during the first $2 \mathrm{wk}$ of the DPH period (when development ends) this species has a holobenthic way of life. A necto-benthic behavior was also observed in Enteroctopus megalocyathus hatchlings during their transition to juvenile phase that took from 5 to $15 \mathrm{DPH}$ (Ortiz et al. 2006). According to Boletzky (1977), Boletzky \& Boletzky (1973) and Zhengzhi (1992), the necto-benthic behavior observed in several cephalopod species, among other processes, is similar to that observed in O. maya in the present study and suggests the evolution from ancestral forms of species whose post-hatching phases had a planktonic life cycle. Kier \& Smith (1990) proposed that the structural differences among sucker structure will then determine attachment force and thus their functionality for benthic life. Although in the present study we did not measure the sucker structure of $O$. maya hatchlings, differences in arm sizes with age could also suggest differences in attachment force with age and differences in the capability of juveniles to maintain their benthic behavior (Voight 1991).

\section{CONCLUSIONS}

In the present study, the period of 10 to $15 \mathrm{DPH}$ can be defined as a transition for Octopus maya before animals reach the true juvenile stage. In the immediate post-hatching period, octopuses showed an important lipidic metabolism related to the use of yolk. That condition provided an increased probability of survival during the first days when food could be limited, mainly when the animals have insufficiently developed arms. In addition, during that time, the holobenthic and non-selective food behavior will allow the dispersal of hatchlings throughout the continental shelf of the Yucatán Peninsula — probably as a result of the
Loop and Yucatan currents through the Yucatan Channel inside the Gulf of Mexico, which constitutes a important component of the circulation in this region (Martínez-Lopez \& Parés-Sierra 1998, Ezer et al. 2003, Oey \& Ezer 2004) — where different niches may be available for juvenile development. Although hatchlings have yolk reserves, we decided that in rearing conditions we would feed octopuses with Artemia and crab meat at $1 \mathrm{DPH}$. That decision took into account that the high variability in growth rate observed in $O$. maya (Briceño et al. 2009) can produce animals that complete their digestive development (i.e. completely developed digestive cells, and enough and stable digestive enzyme levels, among other criteria) sooner than others.

Acknowledgements. C.M. thanks CONACYT for a scholarship. The present study was partially financed by DGAPAUNAM project no. IN 202909-3 and CONACYT-Básico 200724743. We thank R. Cázares and N. Velosa for their invaluable assistance during the behavior treatments.

\section{LITERATURE CITED}

André J, Pecl G, Semmens JM, Grist EPM (2008) Early life-history processes in benthic octopus: relationships between temperature, feeding, food conversion, and growth in juvenile Octopus pallidus. J Exp Mar Biol Ecol 354:81-92

Avila-Poveda OH, Colín-Flores RF, Rosas C (2009) Gonad development during the early life of Octopus maya (Mollusca: Cephalopoda). Biol Bull 216:94-102

Bligh EG, Dyer WJ (1959) A rapid method of total lipid extraction and purification. Can J Biochem Physiol 37:911-931

Boletzky Sv (1975) A contribution to the study of yolk absorption in the Cephalopoda. Zoomorphology 80:229-246

Boletzky Sv (1977) Post-hatching behaviour and mode of life in cephalopods. Symp Zool Soc Lond 38:557-567

Boletzky Sv (1989) Recent studies on spawning, embryonic development, and hatching in the Cephalopoda. Adv Mar Biol 25:85-115

Boletzky Sv, Boletzky MVv (1969) First results in rearing Octopus joubini Robson, 1929. Verh Naturforsch Ges Basel 80:56-61

Boletzky Sv, Boletzky MVv (1973) Observations on the embryonic and early post-embryonic development of Rossia macrosoma (Mollusca, Cephalopoda). Helgol Wiss Meeresunters 25:135-161

Boucaud-Camou E, Boucher-Rodoni R (1983) Feeding and digestion in cephalopods. In: Saleuddin ASM, Wilbur KM (eds) The Mollusca, Vol 5: Physiology, Part 2. Academic Press, New York, p 149-187

Boucher-Rodoni R, Boucaud-Camou E, Mangold K (1987) Feeding and digestion. In: Boyle P (ed) Cephalopod life cycles. Academic Press, London, p 85-108

Bradford MM (1976) A refined and sensitive method for the quantitation of microgram quantities of protein utilizing the principle of protein-dye binding. Anal Biochem 72:248-252

Briceño F, Mascaró M, Rosas C (2009) Modeling the exponential growth in juvenile (siblings) of Octopus maya using glmm: Is growth dependent on initial size? Cephalopod International Advisory Council Symposium, 3-11 Sep 2009, Vigo, Spain 
Budelmann BU, Schipp R, Boletzky Sv (1997) Cephalopoda. In: Harrison FW, Kohn AJ (eds) Microscopy anatomy of invertebrates, Vol 6A: Mollusca II. Wiley-Liss, New York, p $119-414$

Ezer T, Oey LY, Lee HC, Sturges W (2003) The variability of currents in the Yucatan Channel: analysis of results from a numerical ocean model. J Geophys Res C 108:3012, doi: 10.1029/2002JC001509

Fioroni P (1990) Our recent knowledge of the development of the cuttlefish (Sepia officinalis). Zool Anz 224:1-25

Flores EEC (1983) Laboratory observations on the visual attack of the squid, Todarodes pacificus. Mem Mus Victoria 44:205-212

Forsythe JW, Van Heukelem WF (1987) Growth. In: Boyle PR (ed) Cephalopod life cycles, Vol II: comparative reviews. Academic Press, London, p 135-156

Graziadei P (1971) The nervous system of the arms. In: Young JZ (ed) The anatomy of the nervous system of Octopus vulgaris. Clarendon Press, Oxford, p 44-61

Guerin MJ (1908) Contribution a l'étude des systèmes cutané, musculaire et nerveux de l'appareil tentaculaire des céphalopodes. PhD thesis, University of Paris, Fontenayaux-Roses

Hamazaki K, Takeuchi T (2000) Effects of the addition of Nannochloropsis to the rearing water on survival and growth of planktonic larvae in Octopus vulgaris. Saibai-Giken 28: 13-16 (in Japanese)

Hamazaki K, Fukunaga K, Yoshida Y, Maruyama K (1991) Effect of marine microalgae Nannochloropsis sp. on survival and growth on rearing pelagic paralarvae of Octopus vulgaris, and results of mass culture in the tank of 20 metric tons. Saibai-Giken 19:75-84 (in Japanese)

Hjort J (1914) Fluctuations in the great fisheries of Northern Europe in the light of biological research. Rapp PV Réun 20:1-228

Kier WM, Smith AM (1990) The morphology and mechanics of octopus suckers. Biol Bull 178:126-136

Langridge KV (2009) Cuttlefish use startle displays, but not against large predators. Anim Behav 77:847-856

Leporati SC, Pecl GT, Semmens JM (2007) Cephalopod hatchling growth: the effects of initial size and seasonal temperatures. Mar Biol 151:1375-1383

Luna LG (1968) Manual of histologic staining methods of the armed forces institute of pathology, 3rd edn. McGrawHill, New York

Marr JC (1956) The 'critical period' in the early life history of marine fishes. J Cons Int Explor Mer 21:160-170

Martínez-Lopez B, Parés-Sierra A (1998) Circulación del Golfo de México inducida por mareas, viento y la Corriente de Yucatán. Cienc Mar 24:65-93

Mascaró M, Seed R (2001) Foraging behaviour of juvenile Carcinus maenas (L.) and Cancer pagurus L. Mar Biol 139: 1135-1145

Mäthger LM, Barbosa AS, Hanlon RT (2006) Color blindness and contrast perception in cuttlefish (Sepia officinalis) determined by a visual sensorimotor assay. Vision Res 46 : $1746-1753$

May RC (1974) Larval mortality in marine fishes and the critical period concept. In: Blaxter JHS (ed) The early life history of fish. Springer-Verlag, Berlin, p 3-19

Messenger JB (1977) Evidence that octopus is colour blind. J Exp Biol 70:49-55

Moltschaniwskyj N, Johnston D (2006) Evidence that lipid can be digested by the dumpling squid Euprymna tasmanica, but is not stored in the digestive gland. Mar Biol 149: 565-572

Moltschaniwskyj NA, Hall K, Lipinski MR, Marian JEAR and others (2007) Ethical and welfare considerations when using cephalopods as experimental animals. Rev Fish Biol Fish 17:455-476

> Navarro JC, Villanueva R (2003) The fatty acid composition of Octopus vulgaris paralarvae reared with live and inert food: deviation from their natural fatty acid profile. Aquaculture 219:613-631

O'Dor RK, Wells MJ (1975) Control of yolk protein synthesis by Octopus gonadotropin in vivo and in vitro (effects of Octopus gonadotropin). Gen Comp Endocrinol 27:129-135

Oey LY, Ezer T (2004) Modeled and observed empirical orthogonal functions of currents in the Yucatan Channel, Gulf of Mexico. J Geophys Res 109:C08011, doi: 10.1029/ 2004JC002345

Ortiz N, Re ME, Márquez F (2006) First description of eggs, hatchlings and hatchling behaviour of Enteroctopus megalocyathus (Cephalopoda: Octopodidae). J Plankton Res 28:881-890

Perrin A, Le Bihan E, Koueta N (2004) Experimental study of enriched frozen diet on digestive enzymes and growth of juvenile cuttlefish Sepia officinalis L. (Mollusca Cephalopoda). J Exp Mar Biol Ecol 311:267-285

> Pfister CA, Stevens FR (2002) The genesis of size variability in plants and animals. Ecology 83:59-72

Portmann A, Bidder AM (1928) Yolk-absorption in Loligo and the function of the embryonic liver and pancreas. QJ Microsc Sci 72:301-324

Roper CFE, Sweeney MJ (1983) Techniques for fixation, preservation, and curation of cephalopods. Mem Mus Victoria 44: $29-47$

Roper CFE, Voss GL (1983) Guidelines for taxonomic descriptions of cephalopods species. Mem Mus Victoria 44: $49-63$

Rosas C, Caamal C, Cazares R, Rodriguez D, Romero M, Chay D (2006). Manual preliminar para el cultivo del pulpo Octopus maya. UMDI-UNAM, Secretaría de Desarrollo Rural y Pesca, Gobierno de Yucatán, y CONAPESCA, Yucatán

Rosas C, Cazares-Simental RJ, Caamal-Monsreal C, AvilaPoveda $\mathrm{OH}$ and others (2007) Adaptaciones morfológicas y digestivas durante los primeros días de vida de los juveniles del pulpo de costa Octopus maya (Voss y Solis). XIII congreso bienal, Asociación Mexicana de Especialistas en Nutrición Animal, 23-26 Oct, Veracruz, Mexico

> Rosas C, Tut J, Baeza J, Sánchez A and others (2008) Effect of type of binder on growth, digestibility, and energetic balance of Octopus maya. Aquaculture 275:291-297

Segawa S, Hanlon RT (1988) Oxygen consumption and ammonia excretion rates in Octopus maya, Loligo forbesi and Lolliguncula brevis (Mollusca: Cephalopoda). Mar Behav Physiol 13:389-400

Semmens JM (1998) An examination of the role of the digestive gland of two loliginid squids, with respect to lipid: storage or excretion? Proc Biol Sci 265:1685-1690

Semmens JM (2002) Changes in the digestive gland of the loliginid squid Sepioteuthis lessoniana (lesson 1830) associated with feeding. J Exp Mar Biol Ecol 274:19-39

Semmens JM, Pecl GT, Villanueva R, Jouffre D, Sobrino I, Wood JB, Rigby PR (2004) Understanding octopus growth: patterns, variability and physiology. Mar Freshw Res 55: 367-377

> Shaw PW, Sauer WHH (2004) Multiple paternity and complex fertilisation dynamics in the squid Loligo vulgaris reynaudii. Mar Ecol Prog Ser 270:173-179

Smith MS, Fuiman LA (2003) Causes of growth depensation in red drum, Sciaenops ocellatus, larvae. Environ Biol Fishes 66:49-60 
Steer MA, Moltschaniwskyj NA (2007) The effects of egg position, egg mass size, substrate and biofouling on embryo mortality in the squid Sepioteuthis australis. Rev Fish Biol Fish 17:173-182

Swift K, Johnston D, Moltschaniwskyj N (2005) The digestive gland of the southern dumpling squid (Euprymna tasmanica): structure and function. J Exp Mar Biol Ecol 315: 177-186

Vecchione M (1987) Juvenile ecology. In: Boyle PR (ed) Cephalopod life cycles, Vol II: comparative reviews. Academic Press, London, p 61-84

Vecchione M, Hand VA (1989) Digestive-gland histology in paralarval squids (Cephalopoda, Loliginidae). Fish Bull 87:995-1000

Vidal EAG, DiMarco FP, Wormuth JH, Lee PG (2002) Influence of temperature and food availability on survival, growth and yolk utilization in hatchling squid. Bull Mar Sci 71:915-931

Voight JR (1991) Ligula length and courtship in Octopus

Editorial responsibility: Victor Meyer-Rochow,

Bremen, Germany digueti: a potential mechanism of mate choice. Evolution 45:1726-1730

Voight JR, Feldheim K (2009) Microsatellite inheritance and multiple paternity in the deep-sea octopus Graneledone boreopacifica (Mollusca: Cephalopoda). Invertebr Biol 128:26-30

Walter HE (1984) Method with haemoglobin, casein, and azocoll as substrate. In: Bergmeyer HU, Grassl M, Bergmeyer J (eds) Methods of enzymatic analysis, Vol 5, 3rd edn. WileyVCH, Weinheim, p 270-277

- Wells MJ (1958) Factors affecting reactions to Mysis by newly hatched Sepia. Behaviour 13:96-111

Yim M, Boucaud-Camou E (1980) Etude cytologique du développement post-embryonnaire de la glande digestive de Sepia officinalis. Arch Anat Microsc Morphol Exp 69:59-79

Young RE, Harman RF (1988) 'Larva', 'paralarva' and 'subadult' in cephalopod terminology. Malacologia 29:201-207

Zhengzhi D (1992) A comparative study on the early growth stages of cephalopods. Zool Res 13:209-216 (in Chinese)

Submitted: September 18, 2009; Accepted: February 12, 2010 Proofs received from author(s): March 15, 2010 